\title{
FLUCTUATIONS IN OYSTER PRODUCTION IN THE FAL ESTUARY
}

\author{
By J. H. Orton, D.Sc. \\ Professor of Zoology, Liverpool University
}

\section{INTRODUCTION}

In the course of studies during the last five years on the breeding and spat-fall of oysters (Ostrea edulis) on the producing grounds, Blackwater and Roach Rivers, in the Thames Estuary, good spat-falls have been observed. In I935 an exceptionally good fall occurred on these grounds at a period when adult stocks of oysters were at a very low ebb. Good spat-falls have also occurred since that time. It was therefore considered worth while to investigate whether comparatively good spat-falls had occurred also in the Fal Estuary and at the same time compare the existing conditions with those found in surveys in 1924 and 1926 (Orton, I927 $a$ and $b$ ). The Fal Estuary beds may be regarded as at least second in national importance to the Thames Estuary beds for the production of oysters. Moreover, as suggestions have been made that the oyster pest, the American slipper limpet, Crepidula fornicata, might become introduced and establish itself on the Fal beds, it was desirable to find out whether Crepidula had yet been found on the oyster grounds.

By the courtesy of the Truro Town Clerk, Mr L. J. Carlyon, and the River Committee, permission was given for the desired survey, which was carried out on February 23 1939. The expenses of the research were defrayed from a grant from the Durning-Lawrence Bequest, Liverpool University; acknowledgement is gladly tendered.

\section{SURVEY OF THE BEDS}

On the day of the survey only ten boats were at work. Most of the boats were visited in turn and their dredge-hauls scrutinized and recorded. The bailiff, $\mathrm{Mr}$ Tyache, reported that recently about I2 boats per day had been working. From figures of the daily catches of five sailing boats from February 24 to March 3 (kindly supplied along with other valuable assistance by the bailiff, $\mathrm{Mr}$ Tyache), the average daily catch per boat each using two dredges was I33 oysters of legally takeable size, i.e. with minimum span in any direction of $2 \frac{5}{8}$ in. The daily catches ranged from 100 to 207 . The price of these oysters at the time was very low, namely about $4 s .6 d$. per hundred. In the same period the average daily catch per man per rowing boat (haul on tow) was 99 oysters, the daily catches ranging from 79 to 123 .

The state of the beds can be closely estimated from these figures of the daily catches and the detailed report on the examination of the dredge-hauls given in Table I. 


\section{Table I. Analysis of Dredge-hauls for Oysters, Truro Grounds, FAL ESTUARY, FEBRUARY 23 I939}

Ten boats seen at work. Price of oysters $4 s .6 d$. per Ioo

$\overbrace{\begin{array}{c}\text { About } \\ \mathrm{I} \text { in. }\end{array} \quad \mathrm{I}-2 \frac{1}{2} \text { in. }}^{\text {Small oysters }} \quad \begin{gathered}\begin{array}{c}\text { Large } \\ \text { oysters } \\ 2 \frac{5}{8} \text { in. } \\ \text { and over }\end{array} \\ \text { and }\end{gathered}$

Remarks

Haul I. Boathouse

A. River above Turnaware Bar: rowing boats only

Hauls made in absence:

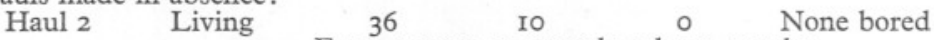

Haul 3. Clenhalls Flat

From 9.30 to I0.45 only 7 large caught
Living
I4
I
II
2 Carcinus with Sacculina

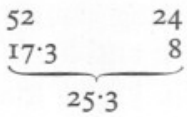

Totals Living

Average living per haul
I

4

80.3

Culch fairly clean and abundant

B. Truro Lake. Turnaware Bar: rowing boat only
I
Living
I7
5
2 Culch very dirty

C. Truro Lake: sailing boats. North and middle of East Bank: sailing boat, good breeze

$\begin{array}{rcrrrl}2,3 & \text { Living } & \text { I3 } & \text { I } & \text { I2 } & 5 \text { one inch dead, none bored } \\ 4,5 & \# & 0 & 4 & 4 & \text { Struck a bed inshore } \\ 6,7 & \# & 30 & 2 & \text { I9 } & 6 \text { spat on a stipes of Laminaria } \\ 8,9 & \# & 20 & 2 & 6 & \text {. }\end{array}$

One shell found February 22 carrying three 1938 spat about $\mathrm{I}$ in.

Culch abundant but very dirty

Parsons Bank: sailing boat, wind slight, one dredge

$\begin{array}{lccccc}\text { IO } & \text { Living } & 4 & \circ & \circ & \text { Good bag of culch } \\ \text { II } & y & 3 & \circ & 4 & \text {, }\end{array}$

One shell found February 22 bearing seven 1938 spat about $\mathrm{I}$ in.

Culch abundant, but very dirty

Mylor Bank to Penarrow: sailing boat, fair breeze

$\begin{array}{lccccc}\text { I2 } & \text { Living } & 4 & \text { I } & 5 & \text { Culch old and heavily over- } \\ \text { I3 } & \# & 0 & \circ & 5 & \text { grown with sponges and } \\ \text { I4 } & \# & 2 & \circ & \circ & \text { Lithothamnion. 2 pairs of } \\ \text { I5 } & \# & \circ & \circ & \text { I } & \text { Archidoris in copula; clump } \\ \text { I6 } & \# & 0 & 0 & 2 & \text { of Buccinum spawn }\end{array}$

Note. No dumps seen in any hauls on any grounds

Sums for I5 hauls Averages per haul

Average total per haul

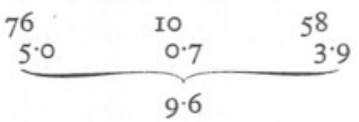

Approximate catch per man per day $=$ I33 legal oysters 
The river beds above Turnaware Bar, Table IA, are fairly well stocked with small oysters, the average haul working out at about $17 \cdot 3$ one year old and 8.0 two or more year old small. These beds, however, at the end of the I938-9 season carried very few large (legal) oysters, only one large oyster being taken in three hauls. It is clear that there had been reasonable spat-falls in 1937 and 1938, but there were few survivors from previous years.

On Turnaware Bar (Table IB) a good supply of I938 young and a few of previous years occurred; these were similar in amount to those found in the river.

On the banks (Table Ic) the supply of small oysters is very poor, not more than four to six per haul being taken in the average haul. Hauls 2, 3, 6 and 7 on the East Bank are probably exceptional, as they were taken from a small patch of ground which could only be worked satisfactorily under the favourable conditions of tide and wind existing at the time. If, therefore, these hauls be excluded the average catch per haul on the banks is 3 one year old, less than I more than one year old small, and 2.4 large, with a total of 6.1 oysters per haul. When the presumed exceptional hauls are included the average rises to 5.1 one year old, 0.7 more than one year old small and 3.9 large, giving a total of 9.7 oysters per haul. Such a high average is seen to be improbable when a comparison is made with those results of extensive dredging in I924 and 1926 given in the reports for those years. The comparison is given in Table II.

\section{Table II. Comparative State of the Beds on the Banks in I924, I926 AND I939}

As indicated by dredge-hauls in sailing boats only

$\begin{array}{ccccccc}\text { Date } & \begin{array}{c}\text { No. of } \\ \text { hauls }\end{array} & \begin{array}{c}\text { Small } \\ \text { per haul }\end{array} & \begin{array}{c}\text { Large } \\ \text { per haul }\end{array} & \begin{array}{c}\text { All } \\ \text { oysters } \\ \text { per haul }\end{array} & \begin{array}{c}\text { Size } \\ \text { of } \\ \text { ring }\end{array} & \begin{array}{c}\text { Daily catch } \\ \text { of large } \\ \text { per man }\end{array} \\ \text { Nov. I924 } & 237 & 6 \cdot 4 & 4 \cdot 2 & \text { IO.6 } & 2 \frac{1}{2} & 300-325 \\ \text { Dec. I926 } & 387 & 2 \cdot 8 & \text { I.3 } & 4 \cdot \text { I } & 2 \frac{5}{8} & \text { About IOO } \\ \text { Feb. I939 } & \text { II } & 3 \cdot 7 & 2 \cdot 4 & 6 \cdot \text { I } & 2 \frac{5}{8} & \text { About I33 }\end{array}$

The results from the small number of dredge-hauls in 1939 in comparison with those for 1924 and 1926 can only be taken as indicative of the conditions on the beds at that time. Since in 1926 a man's daily catch was about Ioo with an average of I.3 oysters per haul, it is probable that in I939 when the average catch was about I33 the average number of large per haul would be $\frac{\mathrm{I} 33}{\mathrm{IOO}} \times \mathrm{I} \cdot 3$, i.e. about $\mathrm{I} \cdot 7$. It is reasonable to infer that the dredging on February 23 I939 was on the whole unusually good and this conclusion is supported by the fact that the sailing boat hauls were taken near the time of low water on a fair spring tide with mostly a good breeze. The figure for the average of small and large oysters per haul may be concluded to be rather higher than would be given by a large number of hauls in variable weather. 
Bearing this in mind it is possible to compare the state of the grounds in the years I924, I926 and 1939 .

The stocks on the beds in 1939 were rather better than in the slump period in 1926 . With the ring at $2 \frac{5}{8}$ in. 4.1 oysters per haul were taken in 1926 and rather more in 1939. In November 1924 when the beds were in a more flourishing state the average number of oysters per haul was 10.6, and 4.2 oysters per haul were legal with the ring at $2 \frac{1}{2}$ in.

\section{Discussion}

Although the beds are a little better than in 1926, the state must be regarded as unsatisfactory. With the favourable weather in recent years for oyster spat-falls the beds on the banks might be expected to show a recovery towards the condition in 1924. The river beds are probably stocked with more young oysters than were on the banks in 1924, and may be considered to be in a fairly satisfactory state. Too few hauls were taken on Turnaware Bar to determine the stock accurately, but the indications are that the stocks of young are very much less than in 1924, when an average of 56.4 young per dredge-haul were taken (Orton, I927a, p. 3I). As Turnaware Bar is a settling ground for spat, heavier stocks might reasonably be expected.

\section{CoNCLUSIONS}

The poverty of the grounds at Turnaware and on the banks in comparison with the reasonable stocks of young in the river is correlated with the presence of clean culch in the river and dirty culch on the banks. In the view of the writer the condition of the culch on the banks is the main deterrent to the recovery of these excellent spatting grounds. In all the hauls seen the culch was abundant but either dirty or, as on the Falmouth North Bank, heavily overgrown with marine organisms, especially with sponges and Lithothamnion.

It was noticed that the dumpy oysters which formed rather more than $40 \%$ of the oyster population in 1924 and 1926 (Orton, I927a, p. 32) were totally absent. In these years the bulk of the dumps were undersize for legal oysters. These dumps which were valuable as a stable spawning stock are not now present on the grounds, with the consequent loss of a real spawning asset to the beds. A fair proportion of older young oysters $I-2 \frac{1}{2}$ in. were found recently dead in the river, but few on the banks. None of these was bored by tingle. No indications of deposits of oil were seen. The American slipper limpet, Crepidula fornicata, was not found, and appears to be unknown.

\section{RECOMMENDATIONS}

The outstanding feature of the beds is the lack of sufficient clean culch on the banks. It is therefore recommended that culch be dredged from the edges of the banks and sides of the Channel (where it is mostly clean) and redistributed over the banks on the same day as dredged. There are other 
ways of supplying the culch necessary but the one suggested seems the simplest. As it will take many years in the economic conditions under which the beds are administered to supply all the culch which might be usefully employed on the banks, it would appear that there should be no delay in making a beginning.

It is suggested that twelve men working six sailing boats might be employed under the supervision of the bailiff for one or two weeks in the year in June catching culch from the edges and spreading it over the banks. In this way clean culch would be available on the banks at about the time the oyster larvae are ready to settle. Perseverance in this procedure may be expected to result in the ultimate recovery of the beds and their maintenance in good condition.

It is recommended that the bailiff be asked to report periodically to the River Committee whether the American slipper limpet has been seen on the beds. Samples of this limpet have been supplied to the bailiff, who will ensure that the dredgermen are also familiar with this important pest in oyster cultivation.

\section{SUMMARY}

A survey of the Fal Estuary Beds in February 1939 gave evidence that the stocks of oysters were only slightly better than in the slump period of 1926 .

The failure of the beds to show the recovery expected in recent years is attributed largely to the absence of sufficient clean culch on the banks.

It is suggested that means be taken to scatter clean culch over the banks in June yearly to prevent further decline of the beds and assist in their more rapid recovery to a flourishing condition.

The American slipper limpet, Crepidula fornicata, was not found and appears to be unknown on the beds.

\section{REFERENCES}

ORTON, J. H., I927a. Report on a survey of the Fal Estuary Oyster Beds (November 1924) with notes on the biology of the oyster, Falmouth I926, p. 29; Summary in fourn. Mar. Biol. Assoc., Vol. xiv, pp. 615-628.

- 1927b. Observations on the Fal Estuary Oyster Beds during 1926, including a study of over-fishing. Fourn. Mar. Biol. Assoc., Vol. xIv, p. 930. 